\title{
Keunggulan Komparatif dan Kompetitif Rempah-Rempah Indonesia di Pasar Internasional
}

\author{
Herdiana Anggrasari ${ }^{*}$ \\ Putri Perdana ${ }^{2}$ \\ Jangkung Handoyo Mulyo ${ }^{3}$ \\ 1,2 Magister Ekonomi Pertanian, Fakultas Pertanian, Universitas Gadjah Mada, Yogyakarta, \\ Indonesia \\ ${ }^{3}$ Fakultas Pertanian, Universitas Gadjah Mada, Yogyakarta, Indonesia \\ *email: herdianaanggrasari@gmail.com \\ Diterima: Oktober 2020; Disetujui: Februari 2021; Dipublish: April 2021
}

\begin{abstract}
Abstrak
Indonesia menjadi salah satu produsen rempah-rempah dan termasuk dalam 5 negara produsen rempah-rempah terbesar di dunia pada komoditas kayu manis, cengkeh, pala, lada, dan vanili, sehingga memiliki peluang dan berpotensi besar untuk dikembangkan. Penelitian ini bertujuan untuk mengetahui daya saing komparatif dan kompetitif komoditas rempah-rempah Indonesia di pasar internasional dibandingkan dengan negara pesaingnya. Penelitian ini menggunakan data sekunder yang diperoleh dari UNComtrade dengan jangka waktu 18 tahun (2000-2017). Metode penelitian deskriptif digunakan dalam penelitian ini. Daya saing komparatif diketahui dengan menggunakan analisis Revealed Comparative Trade Advantage (RCTA) dan Indeks Spesialisasi Perdagangan (ISP) sedangkan daya saing kompetitif diketahui dengan menggunakan Export Product Dynamic (EPD). Hasil penelitian menunjukkan bahwa daya saing komparatif komoditas rempah-rempah Indonesia sangat kuat, namun memiliki daya saing kompetitif yang belum baik karena posisi produk berada pada lost opportunity. Peningkatan kinerja dan daya saing rempahrempah Indonesia dapat dilakukan dengan meningkatkan nilai ekspor rempah-rempah Indonesia dengan memberikan nilai tambah dan peningkatan mutu melalui inovasi teknologi. Selain itu, perlu mengembangkan intelijen pasar dan meningkatkan peran atase dalam diplomasi perdagangan rempah-rempah dengan negara-negara mitra dan negara-negara potensial.
\end{abstract}

Kata Kunci: Ekspor, Komparatif, Kompetitif, Rempah-rempah

\begin{abstract}
Indonesia is one of the spice producers and is one of the 5 largest spice producing countries in the world in the commodity of cinnamon, cloves, nutmeg, pepper, and vanilla so that it has great opportunities and potential to be developed. This study aims to determine the comparative and competitive competitiveness of Indonesian spices in the international market compared to its competitors. This study uses secondary data obtained from UNComtrade with a period of 18 years (2000-2017). The descriptive research method used in this study. Comparative competitiveness is known by using Revealed Comparative Trade Advantage (RCTA) and Trade Specialization Index (ISP) analysis while competitive competitiveness is known by using Export Product Dynamic (EPD). The results showed that the comparative competitiveness of Indonesian spices is very strong, but has not yet good competitive competitiveness because the product position is in a lost opportunity. Improving the performance and competitiveness of Indonesian spices can be done by increasing the export value of Indonesian spices by providing added value and increasing quality through technological innovation. Besides, it is necessary to develop market intelligence and increase the role of attachés in spice trade diplomacy with partner countries and potential countries.
\end{abstract}

Keywords: Comparative, Competitive, Export, Spices 


\section{PENDAHULUAN}

Komoditas

rempah-rempah

Indonesia menjadi salah satu komoditas sub sektor perkebunan yang berpeluang besar di pasar internasional. Sebagai produsen rempah-rempah, Indonesia berpeluang menjadi eksportir rempah dunia. Lakner et al. (2018) mengungkapkan bahwa sejak 1960-an, kuantitas perdagangan rempah-rempah global telah meningkat secara eksponensial, Nilai perdagangan rempah-rempah internasional meningkat 41 kali lipat yang menunjukkan tingkat yang sedikit lebih tinggi dari peningkatan perdagangan makanan secara keseluruhan.

Kedepannya permintaan bahan rempah akan semakin meningkat sejalan dengan pertumbuhan penduduk, perekonomian, tuntutan kesehatan dan semakin mahalnya produk-produk sintetis, juga meningkatnya kesadaran akan kelestarian lingkungan hidup (Ferry, 2013). Tren permintaan komoditas rempah dunia memilki kecenderungan meningkat setiap tahunnya dengan laju permintaan sebesar $10,38 \%$ per tahun. Hal tersebut menunjukkan bahwa komoditas rempah memiliki pasar yang prospektif dan memegang peranan penting di pasar internasional.

Perdagangan internasional yang semakin berkembang pesat akibat liberalisasi perdagangan mengharuskan Indonesia memiliki spesialisasi, diferensiasi dan kemampuan untuk bersaing dalam memperebutkan pasar dunia. Besarnya penguasaan pasar oleh suatu negara dapat menunjukkan daya saing suatu negara pada komoditas tertentu. Data FAO (2018) menunjukkan bahwa pada tahun 2017 Indonesia merupakan salah satu produsen utama komoditas rempah dunia dengan pesaing ekspornya yaitu Vietnam, India, China, Madagaskar, dan Belanda.

Agar dapat berdaya saing di industri yang sama di era liberalisasi ini maka pangsa ekspor komoditas rempahrempah Indonesia harus ditingkatkan dengan memiliki suatu keunggulan yang berbeda dibandingkan dengan negara pesaingnya. Saat ini keunggulan alami yang dimiliki Indonesia adalah jumlah tenaga kerja dan bahan baku yang berlimpah serta ciri khas komoditas rempah Indonesia yang tidak semua negara memilikinya. Selain itu, Indonesia memiliki produksi rempah-rempah yang cukup tinggi. Indonesia termasuk 5 negara produsen pada beberapa komoditas rempah terbesar di dunia yaitu kayu manis, cengkeh, pala, lada, dan vanili. Berkaitan dengan informasi tersebut maka dapat dikatakan bahwa Indonesia cukup memiliki kemampuan dalam memperebutkan pangsa pasar rempah-rempah dunia. Oleh karena itu, evaluasi perbandingan daya saing dengan negara-negara pesaing diperlukan untuk mengetahui posisi Indonesia di pasar internasional.

Studi empiris mengenai keunggulan komparatif dan kompetitif komoditas rempah-rempah di pasar internasional belum banyak dilakukan. Salah satu penelitian terkait dengan daya saing rempah Indonesia adalah Hermawan (2015) yang mengkaji daya saing rempah Indonesia di pasar ASEAN periode pasca dan pra krisis global dengan jangka 
waktu 9 tahun (2005-2013). Hasil penelitian tersebut menunjukkan bahwa daya saing rempah Indonesia di pasar ASEAN mengalami perubahan antar periode pengamatan. Pada periode sebelum dan saat krisis ekonomi banyak komoditas rempah Indonesia berdaya saing rendah, sedangkan pada saat pasca krisis ekonomi kondisi daya saing rempah tersebut mengalami peningkatan, khususnya vanili, kayu manis, jahe, kunyit, safron, timi, daun salam, daun kari, dan lada. Sedangkan, kebaharuan pada penelitian ini ada pada tahun dan cakupan yang diteliti yaitu tahun 2000-2017 dan cakupannya menjadi pasar internasional. Penelitian ini akan memberikan kontribusi dengan melengkapi hasil penelitian yang sudah ada. Penelitian ini menjadi penting untuk dilakukan karena kinerja ekspor dan impor komoditas rempah-rempah Indonesia di pasar internasional dapat diketahui sehingga tingkat keunggulan komparatif dan kompetitif komoditas rempah-rempah Indonesia di pasar internasional yang nantinya dapat digunakan sebagai referensi untuk merumuskan kebijakan yang akan dibuat oleh pemerintah.

\section{METODE PENELITIAN}

Penelitian ini menggunakan metode dasar deskriptif analitis, yaitu metode penelitian yang memusatkan pada pemecahan masalah-masalah aktual pada masa sekarang. Jenis data yang digunakan adalah data sekunder yang diperoleh dari UNComtrade dalam jangka waktu 18 tahun (2000-2017). Data yang digunakan yaitu nilai ekspor komoditas rempah Indonesia dengan negara pesaingnya yaitu Vietnam, India,
Belanda, China, dan Madagaskar. Komoditas rempah-rempah yang digunakan yaitu komoditas sektor pertanian yang mencakup enam kelompok komoditas rempah-rempah, yaitu lada, cabai, dan capsicum (HS 0904), vanili (HS 0905), kayu manis (HS 0906), cengkeh (HS 0907), pala, lawang, kapulaga (HS 0908), dan biofarmaka (HS 0910) yang didasarkan pada kode Harmonized Commodity Description and Coding System (HS).

- Revealed Comparative Trade Advantage (RCTA)

Indeks RCTA (Revealed Comparative Trade Advantage) dapat menggunakan indeks yang dituliskan dalam persamaaan sebagai berikut (Tambunan, 2004):

$R C T A_{i}^{k}=R X A_{i}^{k}-R M A_{i}^{k}$

Keterangan:

$R X A_{i}^{k}=$ Revealed Export

Competitiveness negara i pada

komoditas k ke pasar

internasional.

$R M A_{i}^{k}=$ Revealed Import

Competitiveness negara i pada

komoditas k ke pasar internasional.

Negara memiliki daya saing tinggi bila nilai indeks RCTA positif. Bila nilai indeks RCTA negatif maka negara tersebut memiliki daya saing yang rendah.

- Indeks Spesialisasi Perdagangan (ISP)

Indeks ini digunakan untuk melihat sutau negara cenderung eksportir atau importir terhadap suatu produk. Secara matematis indeks ini dirumuskan sebagai berikut (Ragimun 2012):

$I S P_{i}^{k}=\left(X_{i}^{k}-M_{i}^{k}\right) /\left(X_{i}^{k}+M_{i}^{k}\right)$

Keterangan: 
$X_{i}^{k}=$ Nilai ekspor negara $\mathrm{i}$ pada komoditas $\mathrm{k}$ ke pasar internasional $M_{i}^{k} \quad=$ Nilai ekspor negara $\mathrm{i}$ pada komoditas $\mathrm{k}$ ke pasar internasional

$\mathrm{k}=$ Komoditas rempah-rempah

$\mathrm{i} \quad=$ negara $\mathrm{i}$

Nilai ISP berada di antara -1 dan +1 . Jika nilainya positif (di atas 0 sampai dengan 1), maka dikatakan memiliki daya saing yang kuat atau negara Indonesia cenderung sebagai pengekspor komoditi tersebut. Nilai ISP dapat dikategorikan ke dalam lima tahap yaitu pengenalan $(-1<$ ISP $\leq-0,5)$, substitusi impor $(-0,5<$ ISP $\leq 0)$, perluasan ekspor $(0<$ ISP $\leq 0,8)$, kemandirian $(0,8<$ ISP $\leq 1)$, dan mengimpor kembali (jika nilai ISP kembali menurun, $0<$ ISP $\leq 1$ ) (Hasibuan et al., 2012).

- Export Product Dynamics (EPD)

Export Product Dynamic (EPD) digunakan untuk mengukur dinamika posisi pasar negara tertentu di negara tujuan ekspor. Matrik EPD menggunakan daya tarik pasar (diukur berdasarkan pertumbuhan permintaan) sebagai sumbu horisontal (sumbu X) dan kekuatan bisnis (diukur dari pertumbuhan perolehan pasar/market share) sebagai sumbu vertikal (sumbu Y), menghasilkan 4 kategori posisi pasar yaitu rising star, falling star, lost opportunity, dan retreat (Esterhuizen, 2006).

\section{HASIL DAN PEMBAHASAN}

\section{Revealed Comparative Trade Advantage (RCTA)}

Berdasarkan gambar 1 dapat diketahui bahwa secara keseluruhan perkembangan nilai RCTA komoditas rempah-rempah Indonesia dan negara pesaingnya mengalami fluktuasi selama tahun 2000-2017. Komoditas rempah Vietnam, India, China dan Madagaskar secara konsisten menunjukkan tingkat daya saing relatif baik di setiap tahunnya dengan nilai RCTA komoditas rempah bernilai positif artinya ketiga negara tersebut memliki kinerja perdagangan yang baik dan berdaya saing kuat. Indonesia dan Belanda pernah memiliki nilai RCTA negatif pada tahun tertentu. Pada tahun 2011 Indonesia memiliki nilai RCTA negatif karena meningkatnya impor rempah-rempah Indonesia. Selama 18 tahun nilai RCTA komoditas rempah-rempah Indonesia tertinggi pada tahun 2015 dengan nilai RCTA sebesar 9,50. Pada tahun tersebut komoditas lada, cabai, dan capsicum berkontribusi paling besar dengan nilai ekspor sebesar 559,24 juta US\$ dan laju pertambahan nilai ekspor sebesar 69,45\% dibandingkan tahun sebelumnya. Peningkatan harga lada, cabai, dan capsium dunia dari 4,35 \$/kg menjadi $4,75 \$ / \mathrm{kg}$ merupakan salah satu sebab meningkatnya nilai ekspor.

Berdasarkan perhitungan nilai RCTA selama 18 tahun dapat disimpulkan bahwa Vietnam, India, China, Indonesia, dan Madagaskar memiliki daya saing relatif yang tinggi. Hal ini dilihat baik dari sisi kinerja ekspor maupun perkembangan impor komoditas rempah-rempah masing-masing negara, sedangkan Belanda memiliki daya saing komoditas rempah-rempah yang relatif rendah. Hasil tersebut sesuai dengan penelitian-penelitian sebelumnya yang menunjukkan bahwa daya saing rempahrempah Indonesia relatif tinggi misalnya pala, lawang, kapulaga, lada, dan kunyit 
(Nurhayati, et al., 2019); Heriyanto, 2017; Kurnianto et al., 2016; Agra dan Firdaus 2015). Agar daya saing relatif tetap tinggi, selain mempertahankan kinerja ekspor, suatu negara juga harus memperhatikan perkembangan impornya. Jika laju pertumbuhan impor komoditas rempah-rempah suatu negara lebih besar dibandingkan dengan laju pertumbuhan ekspornya dikhawatikan negara tersebut akan menjadi negara net importir. Oleh karena itu peningkatan produksi dalam negeri dan peningkatan kualitas produk rempah-rempah perlu dilakukan melalui peningkatan produktivitas rempah - rempah dan inovasi teknologi. Hal tersebut seperti yang diungkapkan Ditjenbun (2020) dan Wahyuningsih (2015) dalam penelitiannya bahwa produksi nasional akan mempengaruhi tingkat ekspor.

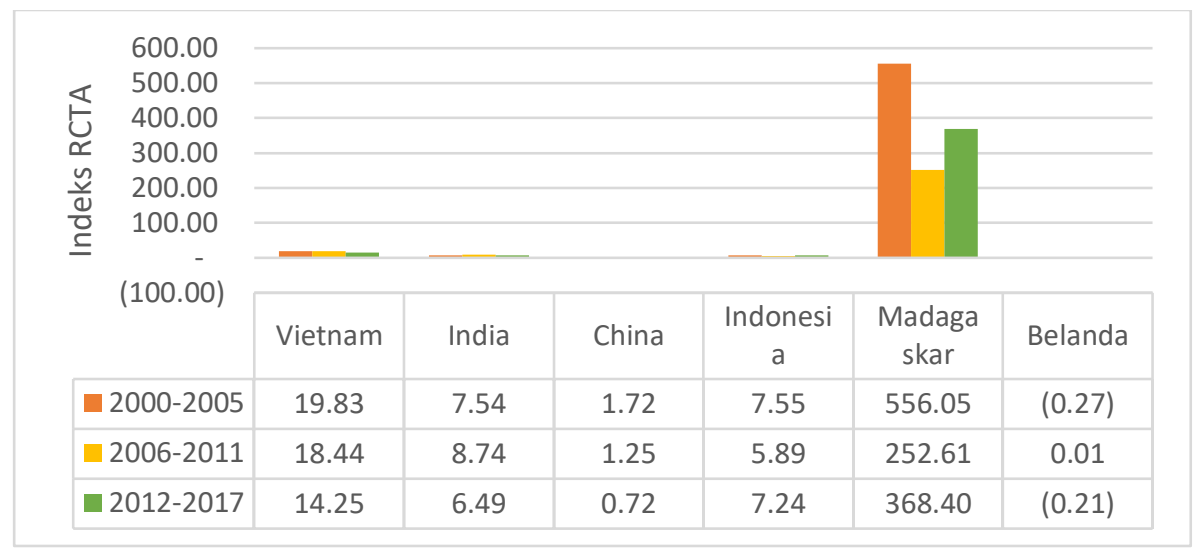

Sumber: Analisis Data Sekunder (UNCOMTRADE, 2019)

Gambar 1. Histogram Pertumbuhan RCTA Komoditas Rempah-Rempah Negara Eksportir Utama Dunia di Pasar Internasional Tahun 2000-2017

\section{Analisis Indeks Spesialisasi Perdagangan (ISP)}

Berdasarkan hasil analisis dari tahun 2000 sampai dengan 2017 rata-rata nilai ISP komoditas rempah-rempah Indonesia bernilai positif. Hal tersebut menunjukkan bahwa penawaran domestik lebih besar dibandingkan permintaannya. Namun, nilai ISP Indonesia terus menurun dikarenakan rata-rata laju pertambahan ekspor komoditas rempah-rempah Indonesia per tahun $8,07 \%$ sedangkan rata-rata laju pertambahan impor komoditas rempah-rempah Indonesia per tahun 92,54\%. Tingginya laju impor rempahrempah Indonesia, salah satunya disebabkan oleh peningkatan impor yang tajam pada komoditas cengkeh (Anggrasari dan Mulyo 2019). Menurut data UNComtrade pada tahun 2010 impor cengkeh Indonesia hanya sekitar 1,3 juta US\$, namun pada tahun 2011 meningkat tajam mencapai 345 juta US\$ kemudian tahun 2012 menurun menjadi 110 juta US\$. Tingginya nilai impor cengkeh disebabkan karena harga cengkeh di pasar internasional yang meningkat sebagai akibat dari turunnya produksi cengkeh dunia. Harga cengkeh meningkat dari 3,65 US\$/kg menjadi 8,11 US $\$ / \mathrm{kg}$ pada tahun 2011. Impor cengkeh dilakukan karena produksi cengkeh domestik yang menurun. Data 
UNComtrade menunjukkan bahwa pada tahun 2011 terjadi penurunan jumlah produksi cengkeh sebesar 26\% (98 ribu ton menjadi 72 ribu ton). Selain itu, menurut data FAO (2018), terjadi penurunan produktivitas cengkeh pada tahun 2011 sebesar 29\%. Pada tahun 2010 produktivitas cengkeh Indonesia mencapai 0,30 ton/ha kemudian turun menjadi 0,21 ton/ha.

Tabel 1. Pertumbuhan ISP Negara Eksportir Rempah-Rempah Utama Dunia Selama 3 Periode Tahun 2000-2017

\begin{tabular}{ccccccc}
\hline Tahun & Vietnam & India & China & Indonesia & Madagaskar & Belanda \\
\hline $2000-2005$ & 0,97 & 0,47 & 0,91 & 0,85 & 0,99 & $-0,07$ \\
$2006-2011$ & 0,84 & 0,58 & 0,93 & 0,76 & 0,99 & 0,08 \\
$2012-2017$ & 0,80 & 0,50 & 0,87 & 0,73 & 0,99 & 0,01 \\
\hline Rerata & 0,87 & 0,52 & 0,90 & 0,78 & 0,99 & 0,01 \\
\hline
\end{tabular}

Sumber: Analisis data sekunder (UNCOMTRADE, 2019)

Tupamahu (2015) menyebutkan bahwa pada periode 2008-2011 keunggulan komparatif cengkeh Indonesia lebih rendah dari rata-rata dunia dan tidak memiliki daya saing. Setelah tahun 2011, terjadi peningkatan produksi cengkeh dengan rerata laju pertambahan produksi $14,7 \%$ setiap tahun sehingga impor cengkeh menurun. Sedangkan pada tahun 2011, pada kelompok komoditas lada, cabai, dan capsicum, kayu manis, pala, lawang, kapulaga dan biofarmaka tidak terjadi peningkatan impor yang signifikan seperti pada komoditas cengkeh. Faktor lain yang dapat mempengaruhi besarnya daya saing yaitu hilangnya pangsa pasar karena adanya peralihan impor oleh negara mitra dagang ke negara pesaing. Misalnya pada tahun 2009 terjadi perubahan komposisi volume impor cengkeh Indonesia yang terjadi di pasar Malaysia karena pada tahun tersebut impor cengkeh di pasar Malaysia banyak beralih ke Singapura (Nurhayati et al., 2018).

Selama tiga periode nilai ISP komoditas rempah-rempah India, China, dan Belanda cenderung berfluktuasi. Sedangkan nilai ISP komoditas rempahrempah Vietnam dan Indonesia cenderung menurun. Hanya Madagaskar yang memiliki nilai ISP komoditas rempah-rempah cenderung konstan dan mendekati satu yang menunjukkan bahwa Madagaskar memasuki tahap kemandirian. Tahap kemandirian yaitu tahap di mana komoditas rempahrempah Madagaskar sudah mengalami standarisasi teknologi dan Madagaskar merupakan negara net exportir. Madagaskar adalah eksportir cengkeh terbesar di dunia yang menjadi salah satu kompetitor terbesar Inonesia. Ekspor Madagaskar ke pasar dunia pada tahun 2016 sebanyak $20.895 .621 \mathrm{~kg}$ atau setara dengan $37,3 \%$ dari ekspor cengkeh dalam perdagangan internasional (Nurhayati et al., 2018).

Naik turunnya nilai ISP dilihat dari kinerja perdagangan komoditas rempahrempah negara tersebut. Jika perkembangan impornya lebih besar dari ekspornya maka nilai ISP dapat menurun apalagi jika impornya meningkat 
Tabel 2. Pertumbuhan Posisi EPD Komoditas Rempah-Rempah Eksportir Utama Dunia di Pasar Internasional Tahun 2000-2017

\begin{tabular}{lccl}
\hline Negara & $\begin{array}{c}\text { Pertumbuhan } \\
\text { pangsa pasar } \\
\text { ekspor (\%) }\end{array}$ & $\begin{array}{c}\text { Pertumbuhan } \\
\text { pangsa pasar } \\
\text { produk (\%) }\end{array}$ & Posisi EPD \\
\hline Vietnam & 2,57 & 10,31 & Rising Star \\
India & $-3,75$ & 5,85 & Lost Opportunity \\
China & $-1,32$ & 7,05 & Lost Opportunity \\
Indonesia & $-5,46$ & 1,03 & Lost Opportunity \\
Madagaskar & 19,52 & 15,52 & Rising Star \\
Belanda & $-6,32$ & 0,07 & Lost Opportunity \\
\hline
\end{tabular}

Sumber: Analisis Data Sekunder (UNCOMTRADE, 2019)

namun kinerja ekspornya justru menurun. Hal tersebut dapat mengurangi daya saing komoditas rempah-rempah di pasar internasional. Agar setiap negara dapat mempertahankan kinerja ekspornya dan komoditas rempah berada pada tahap siklus produk kedewasaan maka setiap negara harus meningkatkan kinerja perdagangannya dengan meningkatkan volume dan nilai ekspor komoditas rempah-rempahnya.

\section{Export Product Dynamic (EPD)}

Analisis EPD digunakan untuk menganalisis dan mengidentifiasikan daya saing kompetitif serta pertumbuhan suatu komoditi pada arus perdagangan ekspor dalam suatu negara. Posisi pasar tersebut dapat diketahui karena metode ini menggunakan share export total dan share export commodity. Dengan menggunakan metode tersebut dapat diketahui apakah komoditi suatu negara berkelanjutan (dinamis) atau tidak (Pradipta dan Firdaus 2014). Pada penelitian ini analisis EPD digunakan untuk menggambarkan posisi daya saing komoditas rempah-rempah secara kompetitif di pasar internasional sehingga komoditas rempah-rempah diantara negara eksportir dapat dibandingkan.

Negara pesaing Indonesia yaitu Vietnam, China, India, Madagaskar, dan Belanda memiliki posisi EPD yang berbeda-beda selama kurun waktu 18 tahun (2000-2017). Negara Vietnam dan Madagaskar berada pada posisi rising star, sedangkan China, India, Indonesia, dan Belanda pada posisi lost opportunity. Pada tabel 3 dapat dilihat pertumbuhan posisi EPD negara eksportir rempah-rempah utama di pasar internasional. Selama 18 tahun dapat dilihat bahwa persentase pertumbuhan pangsa pasar ekspor komoditas rempah-rempah Vietnam dan pertumbuhan pangsa pasar ekspor seluruh komoditas Vietnam bernilai positif dengan nilai 2,57\% dan 10,31\%. Hal tersebut membuat posisi EPD komoditas rempah Vietnam di pasar internasional adalah rising star yang ditunjukkan dengan pertumbuhan pasar 
komoditas rempah-rempah dan pasar ekspor yang positif.

Madagaskar berada dalam kondisi rising star. Posisi pasar komoditas rempah-rempah tersebut memiliki pangsa ekspor yang tinggi. Kondisi tersebut ditandai dengan berkembangnya komoditas rempah-rempah secara cepat dan diiringi oleh semakin luasnya pangsa pasar. Pada kondisi tersebut permintaan produk tersebut tumbuh dengan cepat. Hal tersebut dapat dilihat dari persentase pertumbuhan pangsa pasar ekspor komoditas rempah-rempah Madagaskar yang meningkat 19,52\% dan pertumbuhan pangsa pasar ekspor seluruh komoditas Madagaskar meningkat sebesar $15,52 \%$.

Posisi EPD India, China, Indonesia, dan Belanda memiliki daya tarik pasar yang positif dan daya tarik rempah-rempah yang negatif sehingga posisi komoditas berada pada lost opportunity. Kondisi tersebut menunjukkan bahwa selama 18 tahun komoditas rempah-rempah negara tersebut cenderung mengalami penurunan pangsa pasar di luar negeri, sedangkan daya tarik pasar ekspor di pasar internasional mengalami peningkatan. Kondisi ini mengakibatkan negara-negara tersebut kehilangan kesempatan pangsa atau jangkauan ekspor untuk komoditas rempah-rempah di pasar internasional. Di Indonesia, selama periode 2000-2017 persentase pertumbuhan pangsa pasar ekspor komoditas rempah-rempah Indonesia menurun sebesar $5,46 \%$ dan pertumbuhan pangsa pasar ekspor seluruh komoditas Indonesia meningkat sebesar $\quad 1,03 \%$. Kondisi ini mengakibatkan Indonesia kehilangan kesempatan pangsa atau jangkauan ekspor untuk komoditas rempah-rempah di pasar internasional. Artinya ada kesempatan yang hilang karena adanya penurunan pangsa pasar pada produk yang dinamis, dimana pasokan komoditas rempah-rempah dunia masih lebih besar dibandingkan Indonesia. Hal ini berbanding lurus dengan ISP komoditas rempah-rempah Indonesia yang cenderung menurun, namun berbanding terbalik dengan nilai RCTA rempahrempah Indonesia yang berdaya saing relatif tinggi. Dengan nilai RCTA yang termasuk tinggi harusnya Indonesia mampu menempati posisi rising star, namun karena Indonesia belum dapat memenuhi permintaan pasar komoditas rempah-rempah secara internasional sehingga Indonesia kehilangan peluang untuk menempati posisi tersebut.

\section{Implikasi Kebijakan}

Negara pesaing komoditas rempahrempah Indonesia juga memiliki daya saing yang kuat terutama Madagasakar. Komoditas rempah-rempah Madagaskar merupakan komoditas unggulan ekspor Madagaskar karena proporsi kontribusi ekspornya dapat mencapai 33,27\% pada tahun 2017. Menurunnya kontribusi ekspor komoditas rempah-rempah Indonesia dapat disebabkan karena harga komoditas rempah-rempah Indonesia yang berfluktuasi dan masih rendah. Oleh karena itu pemberian nilai tambah dan kualitas yang baik menjadi indikator yang penting untuk meningkatkan harga komoditas rempah-rempah Indonesia.

Diferensiasi komoditas pertanian sangat penting untuk mengurangi tingkat kompetisi dan persaingan sehingga dapat memperluas jangkauang pasar. 
Diferensiasi produk dapat dilakukan dengan Indikasi Geografis (IG). Indikasi Geografis adalah nama tempat atau sebutan yang digunakan untuk mengidentifikasi komoditas yang berasal dari wilayah geografis tertentu, yang memiliki kualitas, karakteristik dan reputasi khusus yang langsung terkait dengan daerah asalnya, disebabkan oleh faktor alam serta praktik tradisional. Indikasi Geografis juga merupakan bagian dari Hak Kekayaan Intelektual. Tujuh komoditas rempah yang telah dilindungi oleh Indikasi Geografis di Indonesia antara lain: Lada Putih Muntok (terdaftar sejak 2010); Vanili Kep. Alor (terdaftar sejak 2012); Cengkeh Minahasa dan Pala Siau (terdaftar sejak tahun 2015) serta Lada Hitam Lampung, Pala Tomandin Fakfak, Cengkeh Moluku Kie Raha (terdaftar 2016). Sejalan dengan pendapat Chasanah et al. (2017) menyebutkan bahwa komoditas rempah masih meiliki ciri yang relatif spesifik pada kepemilikian endowment factor-nya sehingga tidak semua negara memilikinya. Dengan adanya Indikasi Geografis, komoditas rempah menjadi mempunyai nilai tambah pada pemasaran dengan harga jual yang meningkat karena adanya brand image.

Kelemahan daya saing produk dan komoditas sektor pertanian di Indonesia merupakan salah satu kendala yang harus segera diatasi guna turut bersaing secara baik di pasar global disamping di pasar domestik sendiri. Kelemahan daya saing Indonesia terjadi karena Indonesia masih mengandalkan produk-produk yang dihasilkan dengan dukungan dan basis sumber daya alam dan tenaga kerja (keunggulan komparatif), dan bukan didukung oleh dasar ilmu pengetahuan atau kreativitas yang merupakan salah satu modal besar dalam peningkatan keunggulan kompetitif (Badan Penelitian dan Pengembangan Pertanian 2014). Selain itu penanganan pasca panen yang baik sangat diperlukan untuk menjaga mutu dan kualitas komoditas rempah agar berdaya saing di pasar Internaisonal.

Sebaiknya pemerintah perlu mengadakan pelatihan dan pendampingan kepada petani serta menjaga stabilitas harga rempah-rempah agar petani lebih intensif dalam melakukan budidaya rempah-rempah. Selain itu, inovasi teknologi perlu dilakukan untuk meningkatkan produksi, produktivitas, serta mutu rempahrempah. Peningkatkan produksi produk yang bernilai tambah juga perlu dilakukan untuk meningkatkan nilai kommoditas rempah-rempah di pasar internasional. Indonesia harus bergerak menjauhi produk komoditas primer, melalui pengembangan industri berbasis rempahrempah, yang diperluas ke arah nilai tambah produk hilir secara terintegrasi dengan penelitian dan pengembangan desain produk dan promosi pasar. Pemerintah Indonesia harus membuka akses ke pasar baru yang berpotensi.

Upaya peningkatan ekspor optimal maka Indonesia perlu mencari pasar lain yang sedang tumbuh untuk produk yang mengalami penurunan pangsa pasar Negara tujuan ekspor (Ningsih dan Kurniawan 2016). Untuk meningkatkan nilai ekspor komoditas rempah-rempah, Indonesia dapat melakukan ekspansi pasar ke negara importir dengan mengembangkan intelijen pasar yaitu strategi untuk mendapatkan informasi 
tentang pasar komoditas rempah-rempah dengan mengumpulkan data dan menganalisis pasar sesuai dengan kondisi pasar saat ini. Intelijan pasar (marketing intelligence) sangat penting selain untuk keunggulan bersaing, survive dan mempertahankan daya saing diantara pesaing lama, maupun para pesaing yang sedang masuk dalam segmen pasar yang sama. Intelejensi pasar dapat memberikan kebutuhan informasi untuk pengembangan pemasaran suatu komoditas.

Survei di dalam negeri juga diperlukan untuk menentukan preferensi konsumen dan segmentasi pasar sehingga produsen rempah-rempah Indonesia dapat memenuhi permintaan domestik sehingga dapat mengurangi impor. Konsumen komoditas rempah-rempah domestik tidak hanya dari rumah tangga, namun juga industri. Salah satunya industri rumah makan, semakin banyaknya industri rumah makan di Indonesia membuat permintaan rempah-rempah dalam produk olahan semakin meningkat karena pemakaian yang lebih mudah dan efisien.

\section{SIMPULAN}

Daya saing komparatif komoditas rempah-rempah Indonesia sangat kuat, namun memiliki daya saing kompetitif yang belum baik karena posisi produk berada pada lost opportunity. Secara umum perdagangan komoditas rempahrempah Indonesia masih memiliki peluang yang terbuka lebar di Pasar Internasional. Pangsa pasar komoditas rempah-rempah Indonesia dapat ditingkatkan melalui pengembangan industri berbasis rempah-rempah, yang diperluas ke arah nilai tambah produk hilir secara terintegrasi dengan penelitian dan pengembangan desain produk dan promosi pasar (meningkatkan nilai ekspor). Peningkatan kinerja dan daya saing rempah-rempah Indonesia dapat dilakukan dengan meningkatkan nilai ekspor rempah-rempah Indonesia dengan memberikan nilai tambah dan meningkatkan produksi, produktivitas, dan mutu melalui inovasi teknologi. Selain itu, perlu mengembangkan intelijen pasar dan meningkatkan peran atase dalam diplomasi perdagangan rempah-rempah dengan negara-negara mitra dan negaranegara potensial. Pemerintah perlu mengadakan pelatihan dan pendampingan kepada petani serta menjaga stabilitas harga rempah-rempah agar petani lebih intensif dalam melakukan budidaya rempah-rempah.

\section{DAFTAR PUSTAKA}

Agra, Irgandhini, and Muhammad Firdaus. 2015. "Daya Saing Dan Permintaan Ekspor Produk Biofarmaka Indonesia Di Negara Tujuan Utama Periode 2003-2012." Jurnal Manajemen \& Agribisnis 11(3): 183-98.

Anggrasari, Herdiana, and Jangkung Handoyo Mulyo. 2019. "The Trade Of Indonesian Spice Comodities In International Market." Agro Ekonomi 30(1): 13-26.

Badan Penelitian dan Pengembangan Pertanian. 2014. Memperkuat Daya Saing Produk Pertanian. ed. Haryono. Jakarta: IAARD Press.

Chasanah, Nur, Jangkung Handoyo Mulyo, and Dwidjono Hadi Darwanto. 2017. "Competitiveness and Export Similiarity of Indonesia Horticulture in the ASEAN+3." Agro Ekonomi 28(1): 32-47.

Ditjenbun. 2020. "Peluang Ekspor Perkebunan Masih Bertahan." 
Kementrian Pertanian Direktorat Jenderal Perkebunan: 1.

Esterhuizen, D. 2006. "Measuring and Analysing Competitiveness in the Agribusiness Sector : Methodological And." In , 99-146.

Ferry, Yulius. 2013. "Prospek Pengembanga Kayu Manis (Cinnamomun Burmanii L) Di Indonesia." SIRINOV 1(1): 11-20.

Hasibuan, Abdul Muis, Rita Nurmalina, and Agus Wahyudi. 2012. "Analisis Kinerja Dan Daya Saing Perdagangan Biji Kakao Dan Produk Kakao Olahan Indonesia Di Pasar Internasional." Buletin RISTRI 3(1): 57-70. http://www.ejurnal.litbang.pertania n.go.id/index.php/bultri/article/vie w/1067.

Heriyanto, Asrol. 2017. "Daya Saing Ekspor Pala Indonesia Di Pasar Internasional." Jurbnal Dinamika Pertanian XXXIII(02): 179-88.

Kurnianto, Dini Tri, Suharyono, and Kholid Mawardi. 2016. “Daya Saing Komoditas Lada Indonesia Di Pasar Internasional (Studi Tentang Pasar Lada Indonesia Tahun 2010-2014)." Jurnal Administrasi Bisnis 40(2): 5864.

Lakner, Zoltán, Erzsébet Szabó, Viktória Szűcs, and András Székács. 2018. "Network and Vulnerability Analysis of International Spice Trade." Food Control 83: 141-46.

Ningsih, Endah Ayu, and Wibowo Kurniawan. 2016. “Daya Saing
Dinamis Produk Pertanian Indonesia Di ASEAN Dynamic Revealed Comparative Advantage of Indonesian Agriculture in ASEAN." Jurnal Ekonomi Kuantitatif Terapan 9(2): 117-25.

Nurhayati, Ely, Sri Hartoyo, and Sri Mulatsih. 2018. "Analisis

Pengembangan Ekspor Cengkeh Indonesia." Jurnal Ekono 7(1): 2142.

———. 2019. "Analisis Pengembangan Ekspor Pala, Lawang, Dan Kapulaga Indonesia." Jurnal Ekonomi dan Pembangunan Indonesia 19(2): 17390.

Pradipta, Amalia, and Muhammad Firdaus. 2014. "Posisi Daya Saing Dan Faktor-Faktor Yang Mempengaruhi Ekspor BuahBuahan Indonesia." Jurnal Manajemen dan Agribisnis 11(2): 129-43.

Ragimun. 2012. "Analisis Daya Saing Komoditas Kakao Indonesia." Jurnal Pembangunan Manusia 6(2).

Tambunan, Tulus. 2004. "Globalisasi Dan Perdagangan Internasional."

Tupamahu, Yonette Maya. 2015. "Analisis Daya Saing Ekspor Cengkeh Indonesia Di Kawasan ASEAN Dan Dunia." Agrikan 1(May): 27-35.

Wahyuningsih, Wiwit Santi. 2015. "Analisis Daya Saing Ekspor Sektor Unggulan Di Jawa Tengah." Economics Development Analysis Journal 4(3): 332-49. 